\title{
Revision of Helvetia (Araneae: Salticidae: Heliophaninae)
}

\author{
Gustavo R. S. Ruiz \& Antonio D. Brescovit \\ Laboratório de Artrópodes, Instituto Butantan. Avenida Vital Brazil 1500, 05503-900 São Paulo, São Paulo, Brasil. \\ E-mail: gustavoruiz86@hotmail.com,adbresc@terra.com.br
}

\begin{abstract}
The genus Helvetia Peckham \& Peckham, 1894 is revised. The species $H$. zebrina Simon, 1901 and $H$. zonata Simon, 1901 are synonymized with H. cancrimana (Taczanowski, 1872). The species H. insularis (Banks, 1902) is synonymized with H. albovittata Simon, 1901. The genus Deloripa Simon, 1901 is considered a junior synonym of Helvetia by transfer of its type species, resulting in the new combination Helvetia semialba (Simon, 1901). The species Cotinusa humillima Mello-Leitão, 1943, transferred to Helvetia by Galiano, is revalidated. Helvetia roeweri (Soares \& Camargo, 1948) comb. nov. is transferred from the genus Naubolus Simon, 1901. The epigynal structures of the type species $H$. santarema Peckham \& Peckham, 1894 and those of H. semialba, H. albovittata, H. cancrimana and H. roeweri are illustrated, as well as the palp of $H$. humillima. Helvetia roeweri is redescribed and four new species are described: Helvetia labiata (Rio Grande do Sul, Brazil), Helvetia stridulans (Espírito Santo, Brazil), Helvetia rinaldiae (Pará and São Paulo, Brazil) and Helvetia galianoae (Misiones, Argentina). New records for H. cancrimana, H. albovittata and H. roeweri are given.
\end{abstract}

KEY WORDS. Deloripa; Neotropical Region; systematics; taxonomy.

RESUMO. Revisão de Helvetia (Araneae: Salticidae: Heliophaninae). O gênero Helvetia Peckham \& Peckham, 1894 é revisado. As espécies $H$. zebrina Simon, 1901 e H. zonata Simon, 1901 são sinonimizadas com $H$. cancrimana (Taczanowski, 1872). A espécie H. insularis (Banks, 1902) é sinonimizada com $H$. albovittata Simon, 1901. O gênero Deloripa Simon, 1901 é considerado sinônimo júnior de Helvetia pela transferência de sua espécie-tipo, resultando na nova combinação Helvetia semialba (Simon, 1901). A espécie Cotinusa humillima Mello-Leitão, 1943, transferida para Helvetia por Galiano, é revalidada. Helvetia roeweri (Soares \& Camargo, 1948) comb. nov. é transferida do gênero Naubolus Simon, 1901. As estruturas epiginais da espécie-tipo H. santarema Peckham \& Peckham, 1894 e de H. semialba, H. albovittata, H. cancrimana e H. roeweri são ilustradas, bem como o palpo de H. humillima. Helvetia roeweri é redescrita e quatro espécies novas são descritas: Helvetia labiata (Rio Grande do Sul, Brasil), Helvetia stridulans (Espírito Santo, Brasil), Helvetia rinaldiae (Pará e São Paulo, Brasil) e Helvetia galianoae (Misiones, Argentina). Novos registros de $H$. cancrimana, $H$. albovittata and $H$. roeweri são apresentados.

PALAVRAS-CHAVE. Deloripa; Região Neotropical; sistemática; taxonomia.

The subfamily Heliophaninae Petrunkevitch, 1928 (sensu PrószYNSKi 1976) is composed of species with a bump on the tegulum about $90^{\circ}$ clockwise from the base of the embolus in the left palp viewed from below (MADDISON \& Hedin 2003: 541). It includes a large, well delimited lineage (in which Helvetia belongs) with a stridulatory apparatus (MADDISON \& HEDIN 2003: 541), which generally consists of structures developed on the femora I that are rubbed against a granulose portion of the carapace.

The neotropical genus Helvetia was proposed by РескнAм $\&$ Peскнам (1894) and currently comprises seven nominal species from South America. By examining type specimens and material from South American collections, three synonyms were detected among these species. In addition, a generic synonym is proposed, resulting in a new combination. A second new combination is established by the transfer of a species from Naubolus Simon, 1901. A species described by Mello-Leitão is revalidated and four new species are described, which, after this revision, increases to 11 the number of species in this genus.
These species are very problematical concerning malefemale matches. Since they are not very commonly found in the field, males and females collected in near proximity were often put together as belonging to the same species, a practice that resulted in three species with mismatched males and females. This problem is tentatively corrected in this paper, although resulting in many species for which only one sex is known. The missing males and females are expected to be found and described in future papers.

\section{MATERIAL AND METHODS}

The material examined is deposited in the following institutions (abbreviation and curator in parentheses): Instituto Butantan (IBSP, A.D. Brescovit); Muséum National d’Histoire Naturelle (MNHN, C. Rollard); Museu Paraense Emílio Goeldi (MPEG, A.B. Bonaldo); Museu de Ciências Naturais (MCN, E.H. Buckup); Museu de Zoologia da Universidade de São Paulo (MZSP, R. Pinto da Rocha); Universidade Estadual Paulista, Cam- 
pus de Botucatu (UBTU, I.M.P. Rinaldi); Museo Argentino de Ciências Naturales Bernardino Rivadavia (MACN, C. Scioscia). The measurements are given in millimeters. Scale bars in the plates equal $0.25 \mathrm{~mm}$, except when other measurement is given. The abbreviations used throughout the text are: RTA: retrolateral tibial apophysis; d: dorsal; p: prolateral; r: retrolateral; v: ventral; pr: proximal, di: distal.

\section{Helvetia Peckham \& Peckham, 1894}

Helvetia Peckham \& Peckham, 1894: 119 (type species by monotypy: Helvetia santarema Peckham \& Peckham, 1894); Platnick, 2007.

Deloripa Simon, 1901a: 607 (type species by original designation: Deloripa semialba Simon, 1901); Platnick, 2007. Syn. nov.

Diagnosis. The neotropical genus Helvetia can be distinguished from all the remaining genera of the subfamily Heliophaninae by having a trapezoid carapace, which is much wider at the posterior region than it is at the region of the anterior eye row (Fig. 8).

Description. Small spiders (about 3-6 mm) with low, elongated carapace and long abdomen (Fig. 1). Abdominal color patterns include pairs of light patches on a dark background, which can be fused forming transverse stripes (Fig. 1), dark abdomen with a large patch of light scales covering the entire abdomen and longitudinal stripes of dark scales on a light background (Fig. 8). Chelicerae about one third of carapace length, almost vertical (Fig. 1), with two teeth on promargin and one on retromargin. Legs I usually strongest and darkest, strongly developed in some species (Fig. 1). Palps have the heliophanine bump and can have a short embolus, originating distally on the prolateral side of the tegulum and a short RTA (Figs 15 and 16), or can exhibit extensive modifications, such as a very long embolus associated with a counterclockwise rotation of the tegulum in the left palp (Fig. 19), grooves on the cymbium to hold the tip of the curling embolus (Fig. 18), bifid RTA, with a developed ventral branch (Fig. 20) or with a very developed dorsal branch (see Galiano 1976, fig. 10). Epigyna vary from very short copulatory ducts (Figs 4 and 5) to coiled, very long copulatory ducts (Figs 11-14), on whose medial part there is a pair of glandular swollen areas; copulatory openings are usually well separated from each other (Figs 4, 6, 9, and 13), but can be found close together, forming a median small atrium (Fig. 11) or on the internal wall of a very large, deep atrium (Figs 21 and 22); the epigynal pockets can be fused (Fig. 4), medially placed (Figs 7 and 10) or separated into a pair of lateral pockets (Figs 12 and 14), which can be connected in some species. The stridulatory apparatus consists in this group of a series of three modified setae dorsally on the distal portion of the femur I (Figs 1 and 3) and a granulose area laterally on the anterior portion of the carapace (Figs 1 and 2), extending from the anterior lateral eyes to the region behind the posterior lateral eyes.

Distribution. Known only from South America.

\section{Helvetia cancrimana (Taczanowski, 1872)}

\section{Figs 1-5}

Attus cancrimanus Taczanowski, 1872: 68 (male lectotype and male and juvenile paralectotypes from Uassa, French Guyana, R. Jelski leg., deposited in Polska Akademia Nauk, not examined).

Helvetia zebrina Simon, 1901b: 158 (female lectotype and female paralectotype from Mato Grosso, Brazil, Germain leg., deposited in MNHN 21184, examined); Galiano, 1963a: 362, pl. XIX, fig. 15; Platnick, 2007. Syn. nov.

Helvetia zonata Simon, 1901b: 158 (female holotype from São Paulo de Olivença, Amazonas, Brazil, de Mathan leg., deposited in MNHN 20726, examined); Galiano 1963a: 363, pl. XIX, fig. 14; Galiano 1963b: 3, pl. I, fig. 1-6; Platnick, 2007. Syn. nov.

Deloripa quadrifasciata Mello-Leitão, 1945: 280, fig. 71 (female holotype from Goya, Corrientes, Argentina, deposited in Museo de la La Plata 16760, not examined). Synonymized by Galiano, 1963b: 3.

Helvetia cancrimana: Galiano, 1976: 51, figs 1-7; Platnick, 2007.

Note. Since the type specimens of Attus cancrimanus have not been examined, the synonymy is established based on the very good illustrations by Galiano (1976, figs 1-7).

Diagnosis. Males of Helvetia cancrimana are similar to those of $H$. humillima by having a RTA with a very developed dorsal branch (Fig. 18; see GaLiano 1976, fig. 5), but differ by not having a ventral tiny projection on the base of the RTA and by having a shorter embolus.

Description. Male. Described by GaLiano (1976: 53).

Female. Described by Galiano (1963a: 363, under H. zonata).

New records. Brazil, Goiás: Minaçu, Usina Hidrelétrica Serra da Mesa, 1 male, 18-30.XI.1996, A.B. Bonaldo \& L. Moura leg. (MCN 28134); Mato Grosso do Sul: Corumbá, 1 male, 30.IX.2002, Equipe Jauru leg. (IBSP 78639); Brasilândia, Fazenda Cisalpina, Usina Hidrelétrica Sérgio Motta, 3 males and 8 females, 1825.VI.2000, Equipe IBSP leg. (IBSP 30316, 30333, 30751, 30762, 30960, 31128, 31198, 31382, 31435, 31453); São Paulo: Pereira Barreto, Usina Hidrelétrica de Três Irmãos, 1 male, X.1990, M. Costa \& C.R. Bertim leg. (IBSP 4823); Porto Primavera, Usina Hidrelétrica Sérgio Motta, 9 males and 7 females, 2001, Equipe IBSP leg. (IBSP 53077, 53170, 78636); Presidente Epitácio, 1 male, 20-25.III.2001, J.P. Guadanucci \& R. Bertani leg. (IBSP 53197); Rio Grande do Sul: Barra do Ribeiro, Fazenda Boa Vista, 1 female, 16.V.2003, R.S. Araújo leg. (MCN 35682); Palmares do Sul (Buraco Quente), 1 male and 3 females, 11.XI.2003, Equipe Probio leg. (MCN 36880); (Lagoa do Casamento, Ilha Grande), 2 females, 9.IV.2003, Equipe Probio leg. (MCN 35362); Capivari, Lagoa Capivari, 1 female, 20.V.2004, Equipe Probio leg. (MCN 37536).

Distribution. Known from French Guyana and widely distributed in Brazil (states of Amazonas, Mato Grosso, Goiás, Mato Grosso do Sul, São Paulo and Rio Grande do Sul) and Argentina (see Galiano 1963b: 4). 

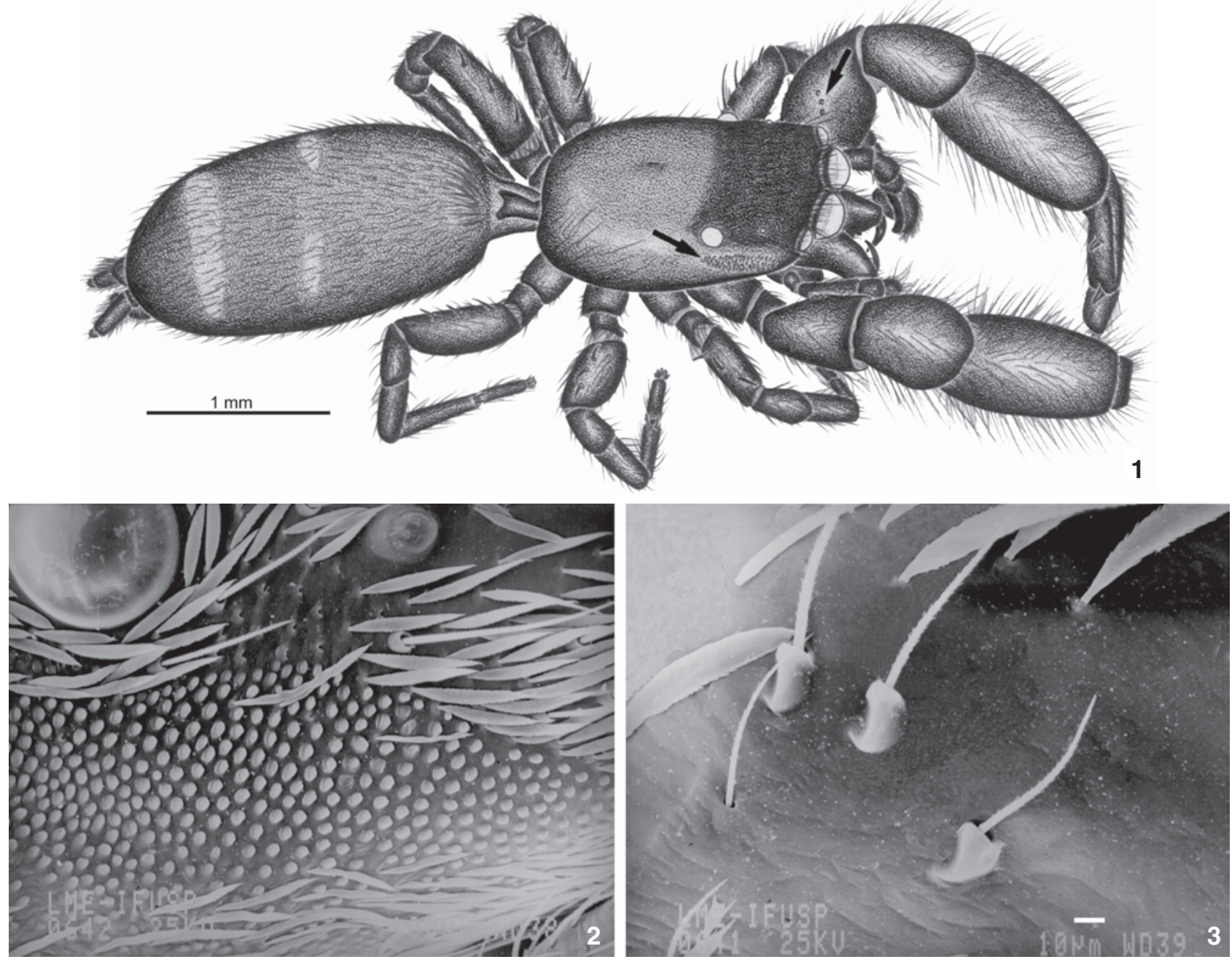

Figures 1-3. Helvetia cancrimana: (1) male, laterodorsal view, arrows show the stridulatory apparatus on femur I and carapace; (2) stridulatory apparatus, rugose portion of lateral carapace; (3) modified femoral setae of the stridulatory apparatus.

\section{Helvetia labiata sp. nov.}

Figs 6-7

Type. Female holotype from Barragem Itaúba, Estrela Velha, Rio Grande do Sul, Brazil, 28.X.1999, A.H. Silva leg., deposited in MCN 31552.

Etymology. The specific name is a Latin word meaning lipshaped and refers to the posterior part of the epigynum, with a "lip" formed by the posterior epigynal edge and by an anterior edge resulting from the medial junction of the copulatory openings.

Diagnosis. This species seems to be closely related to $H$. semialba by having copulatory ducts with similar length and shape, but can be differentiated by the shorter copulatory ducts, seen ventrally through the translucent epigynal integument (Figs 6 and 7).

Description. Female (holotype). Total length: 5.80. Carapace brown, 1.90 long, 1.15 wide, 0.60 high, with a narrow black stripe marginally and sparse white scales. Cephalic region black. Ocular quadrangle 0.90 long. Anterior eye row 0.95 wide and posterior 1.00 wide. Chelicera dark brown. Endite, labium and sternum brown. Palp yellow. Legs 4312 orange, I with brown stripes on metatarsus and tarsus. Length of femur: I 0.75, II 0.65, III 0.75, IV 1.10; patella + tibia: I 1.00, II 0.80, III 0.80, IV 1.25; metatarsus + tarsus: I 0.60, II 0.60, III 0.90, IV 1.00. Spination. Femur I, II, III, IV d1-1-1; tibia I v2, II v1r, III v1di, IV v2di; metatarsus I, II v2-2, III, IV v0-3, p1di, r1di. Abdomen gray, with two longitudinal paramedian dark stripes extending to the posterior third, followed by transverse dark stripes; ventrally cream colored. Epigynum as in figures 6 and 7. Spinnerets dark gray.

Male. Unknown.

Additional material examined. None.

Distribution. Known only from the state of Rio Grande do Sul, Brazil.

Revista Brasileira de Zoologia 25 (1): 139-147, March, 2008 


\section{Helvetia semialba (Simon, 1901) comb. nov. Figs 8-10}

Deloripa semialba Simon, 1901b: 157 (female holotype from Serra do Caraça, Catas Altas, Minas Gerais, Brazil, Gounelle leg., deposited in MNHN 7735, examined); Galiano, 1963a: 342, pl. XVIII, fig. 8; Platnick, 2007.

Diagnosis. This species is similar to H. labiata by having copulatory ducts with similar length and shape, but can be distinguished by the longer copulatory ducts seen in ventral view, overlaying medially (Figs 9 and 10).

Description. Female. Described by Galiano (1963a: 342, under Deloripa semialba).

Male. Unknown.

Additional material examined. None.

Distribution. Known only from Minas Gerais, Brazil.

\section{Helvetia santarema Peckham \& Peckham, 1894 Figs 11-12}

Helvetia santarema Peckham \& Peckham, 1894: 119, pl. 12, figs 2, 2a-d (three female syntypes from Santarém, Pará, Brazil, deposited in Museum of Comparative Zoology, not examined); Galiano 1963b: 2, pl. I, figs 7-10; Galiano, 1965: 48, fig. 9; Platnick, 2007.

Helvetia riojanensis; Galiano, 1965: 50, figs 5-6 (female paratype misidentified).

Cotinusa humillima; Galiano, 1963b: 2 (mismatched male, erroneously synonymized with $H$. santarema, revalidated in this paper); Galiano, 1965: 47.

Note. Since the type specimens of Helvetia santarema have not been examined, the synonymy is established based on the good illustrations by Рескнам \& Рескнам (1894, figs 2, 2a-d).

Diagnosis. Females of Helvetia santarema are similar to those of $H$. albovittata because of the very long copulatory ducts (Fig. 12), but can be distinguished by having very closely set copulatory openings, forming an atrium (Fig. 11).

Description. Female. Described by Pecкham \& Pecкham (1894: 119).

Male. Unknown.

Note. GaLiano (1963b) supposedly found the male of this species described by Mello-Leitão as Cotinusa humillima, synonymizing these species. This male has a shorter embolus than that expected to be present in this species. The general epigynal conformation of $H$. santarema is very close to that of $H$. albovittata, with very long copulatory ducts. The male of $H$. albovittata, however, has a very long embolus, arising very proximally in the palp and making a loop on the retrolateral, distal part of the cymbium, which is itself modified to hold it. Since there seems to be a very strong correlation between the length of the embolus and the length of the copulatory ducts, Galiano's establishment is considered erroneous and Cotinusa humillima is revalidated.

Material examined. Argentina, Misiones: 1 female, X.1943, J. Viana leg. (MACN 5110).

Revista Brasileira de Zoologia 25 (1): 139-147, March, 2008
Distribution. Known from Argentina (see also GaLiano 1965: 50) and from the state of Pará, Brazil.

\section{Helvetia albovittata Simon, 1901 Figs 13-14}

Helvetia albovittata Simon, 1901b: 157 (female holotype from Paraguay, Germain leg., deposited in MNHN 9341, examined); Galiano, 1963a: 361, pl. XIX, fig. 17; Galiano, 1965: 47, figs 78 (misidentified male, actually H. galianoae sp. nov. described in this paper); Platnick, 2007.

Admestina insularis Banks, 1902: 66, pl. 2, fig. 4 (male holotype from Narborough, Galapagos Islands, 4.VII.1899, Hopkins \& Stanford Expedition leg., deposited in American Museum of Natural History, not examined). Syn. nov.

Helvetia otiosa Galiano, 1976: 54, figs 8-12 (male holotype from Embalse, Córdoba, Argentina, 27.XII.1974, M.E. Galiano leg., deposited in MACN 6737, not examined). Synonymized with H. insularis by Galiano 1989: 49.

Helvetia insularis; Galiano, 1989: 49; Platnick, 2007.

Note. Since the type specimen of Admestina insularis has not been examined, the synonymy is established based on the very good illustrations of Helvetia otiosa by GaLIANO (1976, figs 8-12).

Diagnosis. The male of this species is easily dintinguished from the remaining species of the genus by the very long embolus, the form of the RTA and the presence of a depression on the retrolateral cymbium where the tip of the embolus is held in resting position (see Galiano 1976, figs 10-11). Females are very like those of $H$. santarema but can be distinguished by the medial posterior fusion of the copulatory openings, like that of H. labiata (Fig. 13).

Description. Male. Described by GaLIANo (1976: 54, under H. otiosa).

Female. Described by Galiano (1963a: 361).

New records. Brazil, São Paulo: Primavera (Usina Hidrelétrica Sérgio Motta), 8 males and 7 females, 2001, Equipe IBSP leg. (IBSP 53068, 53152); Santa Catarina: Caçador, 1 male, X.1982, D. Lorenzato leg. (IBSP 4255).

Distribution. Known from Ecuador (Galapagos Islands, possibly introduced), Paraguay, Argentina, and from the states of São Paulo and Santa Catarina, Brazil.

\section{Helvetia galianoae sp. nov. Figs 15-16}

Helvetia albovittata; Galiano, 1965: 47, figs 7-8 (only the male allotype, mismatched).

Type. Male holotype from San Javier, Misiones, Argentina, XI.1948, Birabén leg., deposited in MACN 5744.

Etymology. The species is named in honour of the Argentine arachnologist María Elena Galiano.

Diagnosis. Males of this species are very similar to those of $H$. riojanensis by the shape of the RTA (see GaLIANo 1965, fig. $3)$, from which they can be distinguished by having a more 

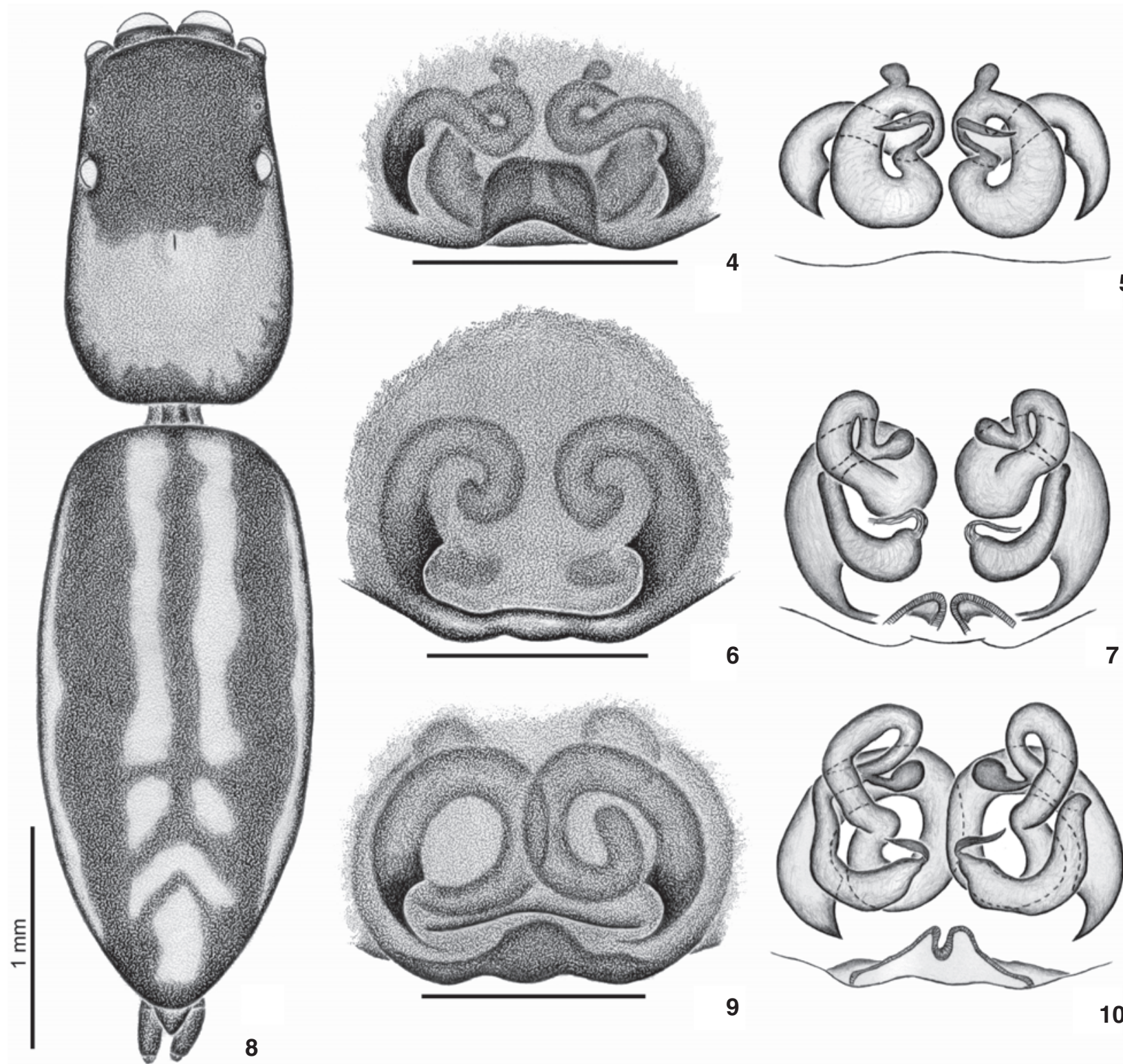

5

6
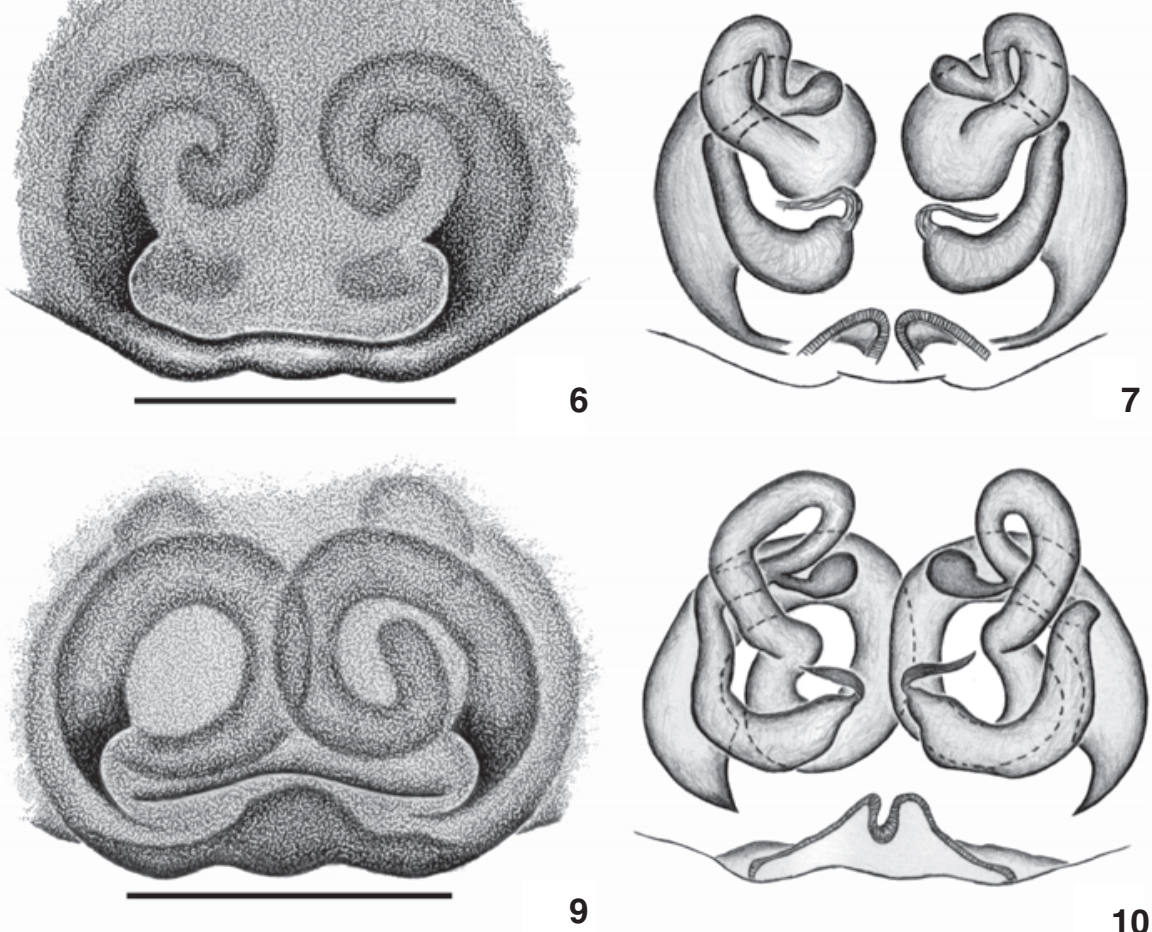

9

Figures 4-10. Epigynum of (4-5) Helvetia cancrimana: (4) ventral view, (5) dorsal view; (6-7) Helvetia labiata: (6) ventral view, (7) dorsal view; (8-10) Helvetia semialba: (8) female holotype, dorsal view, (9) epigynum, vental view, (10) dorsal view. Bars = $0.25 \mathrm{~mm}$, except for fig. $8=1 \mathrm{~mm}$.

slender cymbium seen in ventral view (Fig. 15) and shorter RTA branches (Fig. 16).

Description. Male (holotype). Total length: 4.75. Carapace dark brown, 2.00 long, 1.25 wide, 0.90 high, with a narrow marginal stripe of white scales. Cephalic region black. Ocular quadrangle 0.90 long. Anterior eye row 0.95 wide and posterior 0.95 wide. Chelicera reddish brown. Endite, labium and sternum dark brown. Palp as in Figs 15 and 16. Legs 1432, light brown, with longitudinal black stripes on the tibiae and meta- tarsi II-IV. Length of femur: I 1.05, II 0.75, III 0.80, IV 1.10; patella + tibia: I 1.70, II 0.95, III 0.95, IV 1.35; metatarsus + tarsus: I 0.90, II 0.60, III 0.90, IV 1.05. Spination. Femur I, II, III, IV d11; tibia I 0, II v1pr, III v1di, IV v2di; metatarsus I, II v2-2, III v1di, p1, r1, IV v2di, p1, r1. Abdomen dark brown, with two transverse white marks. Anterior and posterior spinnerets brown.

Female. Unknown.

Additional material examined. None.

Distribution. Known only from Misiones, Argentina.

Revista Brasileira de Zoologia 25 (1): 139-147, March, 2008 


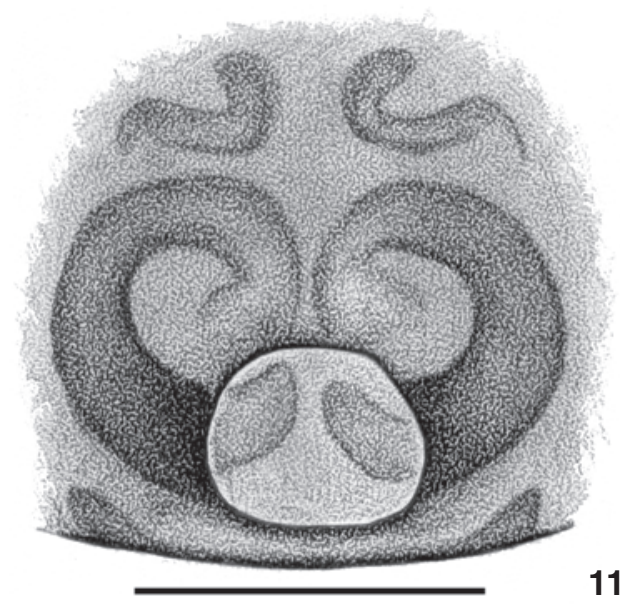

11

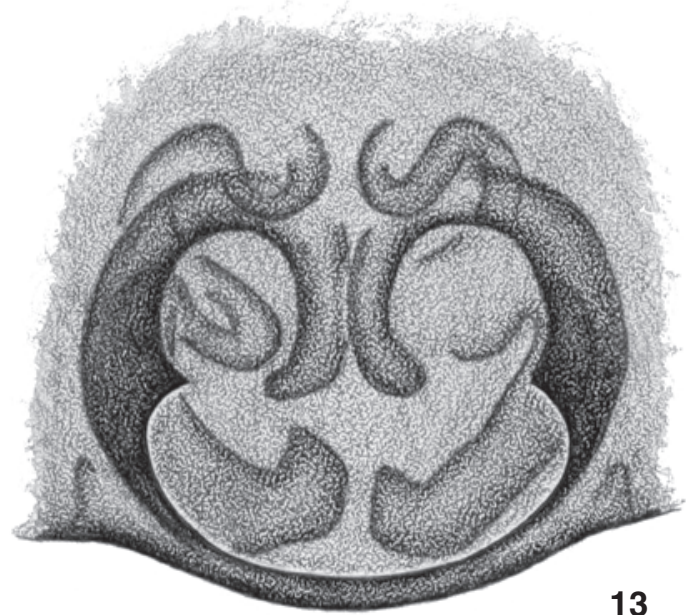

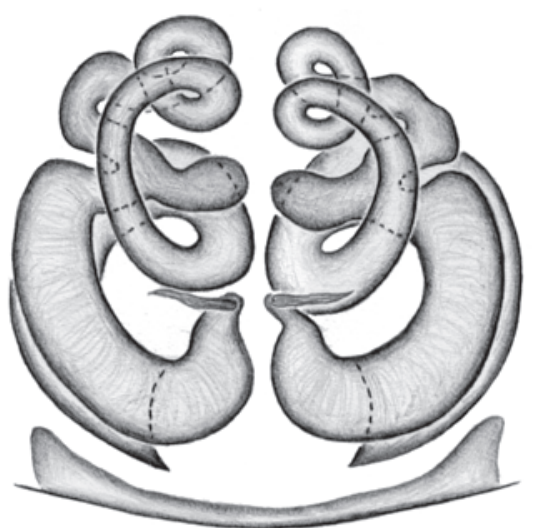

12

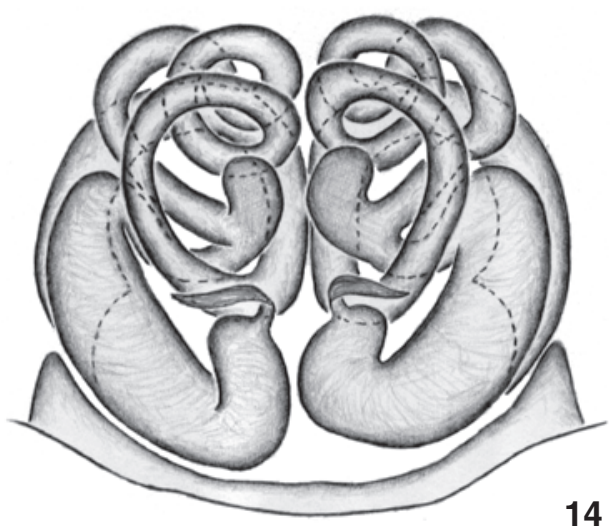

Figures 11-14. Epigynum of (11-12) Helvetia santarema: (11) ventral view, (12) dorsal view; (13-14) Helvetia albovittata: (13) ventral view, (14) dorsal view. Bars $=0.25 \mathrm{~mm}$.

\section{Helvetia riojanensis Galiano, 1965}

Helvetia riojanensis Galiano, 1965: 47, figs 1-4 (male holotype from Guayapa, Patquía, La Rioja, Argentina, XI.1959, M.J. Viana leg., deposited in MACN 5746, not examined); Platnick, 2007. Helvetia santarema, Galiano, 1965: 47, figs 5-6, mismatched female paratype.

Note. Since the type specimen of $H$. riojanensis has not been examined, the identification and diagnosis of this species is based on the illustrations and description by GaLIANO (1965).

Diagnosis. Males of this species are very similar to those of $H$. galianoae by the shape of the RTA, from which they can be distinguished by having a stout cymbium seen in ventral view and longer RTA branches (see GaLiano 1965, figs 1 and 3).

Description. Male. Described by Galiano (1965: 49).

Female. Unknown.

Distribution. Known only from type locality.

Revista Brasileira de Zoologia 25 (1): 139-147, March, 2008

\section{Helvetia humillima (Mello-Leitão, 1943), sp. reval. Figs 17-18}

Cotinusa humillima Mello-Leitão, 1943: 223, fig. 49 [male holotype from Itapiranga, Santa Catarina (not Rio Grande do Sul, as in Mello-Leitão, 1943), Brazil, P. Buck leg., deposited in MNRJ 41937, not examined].

Helvetia humillima: Galiano, 1963b: 2 (synonymized with $H$. santarema); Galiano, 1965: 47.

Note. Since the type specimen of Cotinusa humillima has not been examined, the identification of this species is based on the good illustrations by GaLIano (1963b: figs 8-10, 1965: fig. 9).

Diagnosis. The male of this species has a RTA very similar to that of $H$. cancrimana, with a short ventral branch and a developed dorsal branch, but can be distinguished by the ventral basal projection on the RTA (Fig. 18) and the longer embolus (Fig. 17).

Description. Male. Described by Galiano (1963b: 2, under H. santarema). 

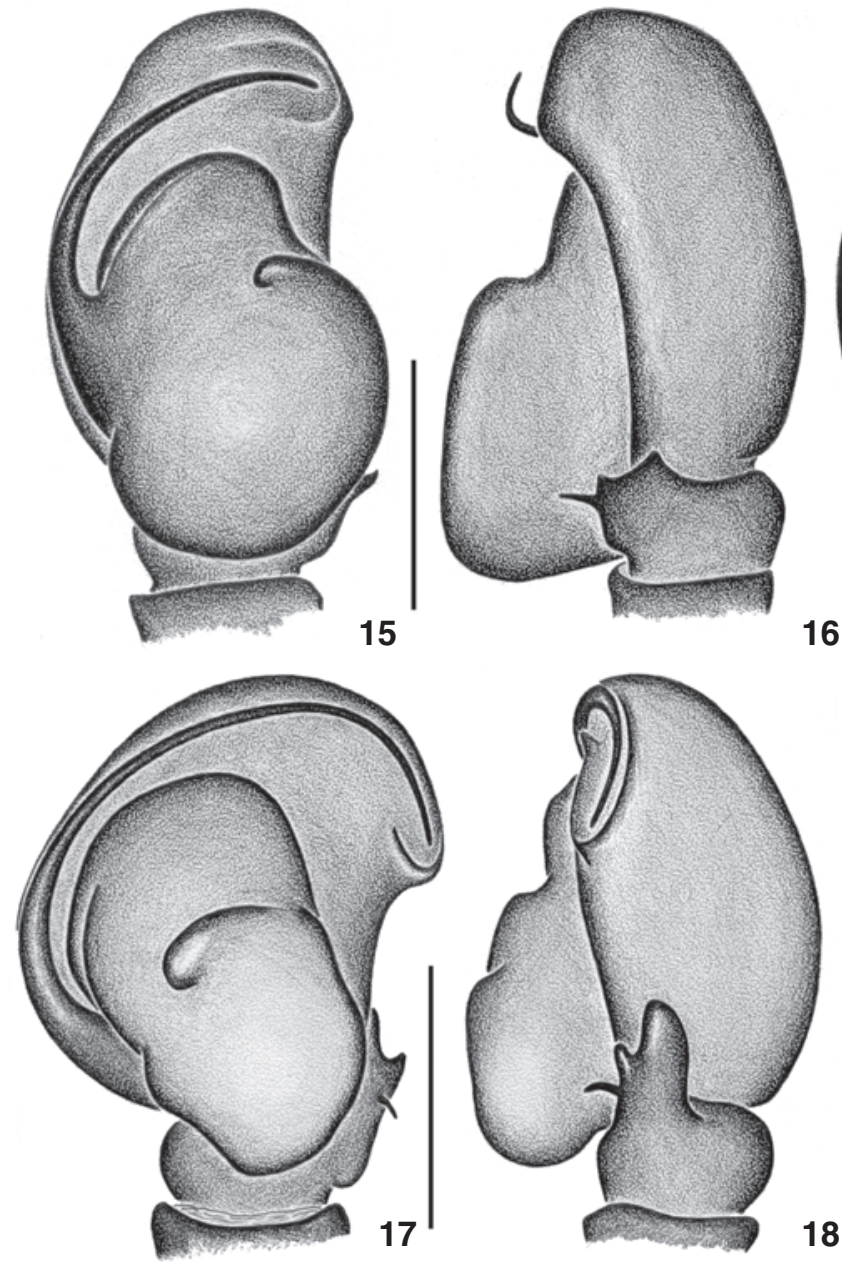

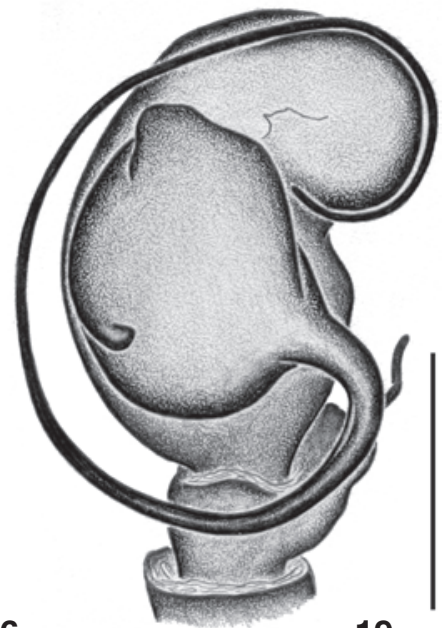

19

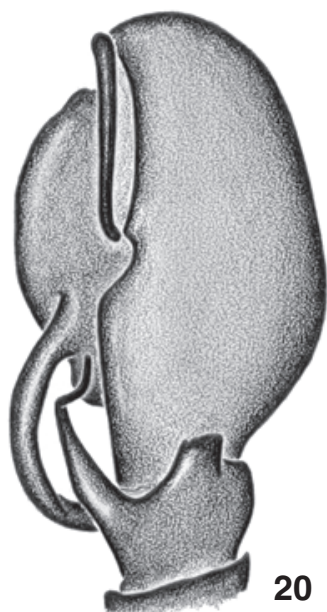

Figures 15-20. Left palp of (15-16) Helvetia galianoae: (15) ventral view, (16) retrolateral view; (17-18) Helvetia humillima: (17) ventral view, (18) retrolateral view; (19-20) Helvetia stridulans: (19) vental view, (20) retrolareal view. Bars $=0.25 \mathrm{~mm}$.

Female. Unknown.

Material examined. BRAzIL, Santa Catarina: Paulo Lopes (Parque Estadual do Tabuleiro, $\left.27^{\circ} 55^{\prime} \mathrm{S}, 48^{\circ} 42^{\prime} \mathrm{W}\right), 1$ male, 10 20.I.2003, Equipe Biota leg. (IBSP 78637).

Distribution. Known only from the state of Santa Catarina, Brazil.

\section{Helvetia stridulans sp. nov.}

Figs $19-20$

Type. Male holotype from AFA Jacarenema, Vila Velha, Espírito Santo, Brazil, 12.X.2005, Exp. ESFA leg., deposited in IBSP 78638.

Etymology. The specific name is a present participle taken from Latin and refers to the stridulatory apparatus on the femora I and carapace of most Heliophaninae.

Diagnosis. Male of this species can easily be recognized by very long embolus, arising proximally from the retrolateral side of the tegulum and having a retrolateral loop on its tip (Fig. 19). This is also the only known species that has a ventral branch more developed than the dorsal branch of the RTA (Fig. 20).

Description. Male (holotype). Total length: 3.40. Carapace brown, 1.60 long, 0.90 wide, 0.55 high, with white scales laterally. Cephalic area black. Ocular quadrangle 0.75 long. Anterior eye row 0.85 wide and posterior 0.80 wide. Chelicera dark brown. Endite, labium and sternum brown. Palp as in figures 19 and 20. Legs 4132, I black, with femur and patella brown, II-IV whitish with few brown stripes. Length of femur: I 0.65, II 0.60, III 0.65, IV 0.85; patella + tibia: I 1.05, II 0.70, III 0.70, IV 1.00; metatarsus + tarsus: I 0.55, II 0.50, III 0.70, IV 0.80. Spination. Femur I, II, III, IV d1-1-1; tibia I 0, II v1pr, III 0, IV v1-0-2; metatarsus I v2-2, II 1rpr, III p1di, r1di, IV v2di, p1di, r1di. Abdomen brown, with a pair of white spots on the anterior third and two transverse median white stripes. Spinnerets black.

Female. Unknown.

Revista Brasileira de Zoologia 25 (1): 139-147, March, 2008 


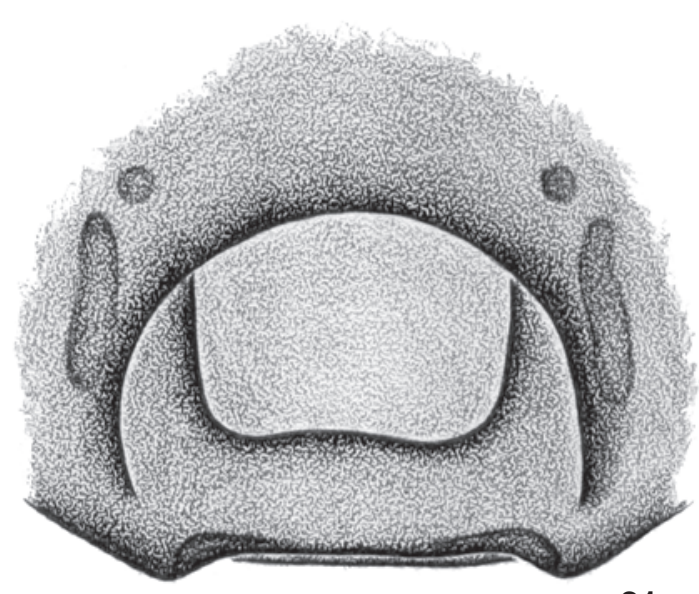

21

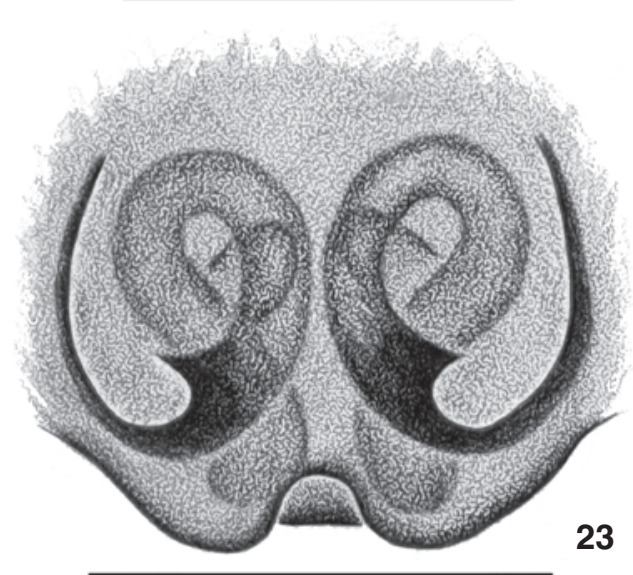

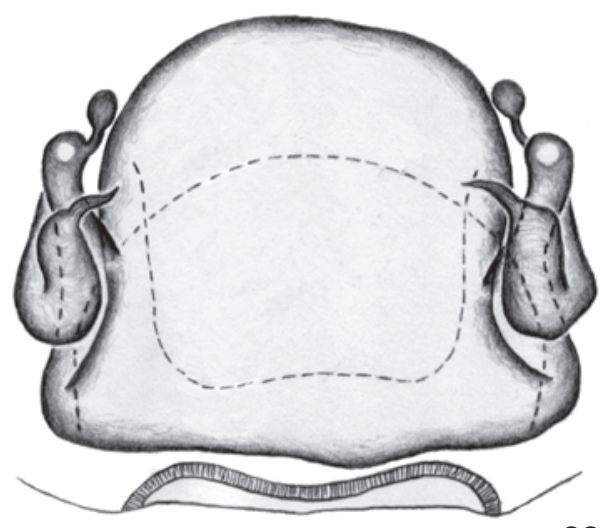

22

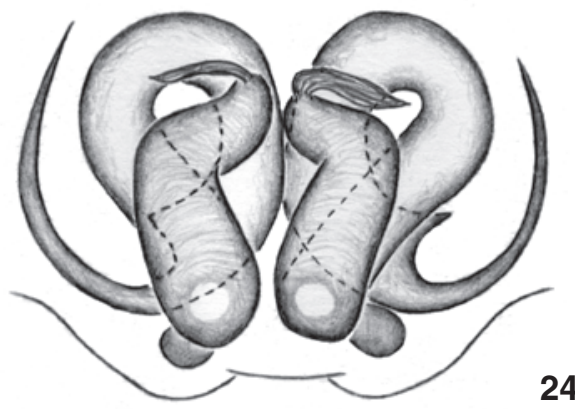

Figures 21-24. Epigynum of (21-22) Helvetia rinaldiae: (21) ventral view, (22) dorsal view; (23-24) Helvetia roeweri: (23) ventral view, (24) dorsal view. Bars $=0.25 \mathrm{~mm}$.

Additional material examined. None.

Distribution. Known only from the state of Espírito Santo, Brazil.

\section{Helvetia rinaldiae sp. nov.}

Figs 21-22

Types. Female holotype from Serra do Cachimbo, Novo Progresso, Pará, Brazil, deposited in MPEG 2088; female paratype from Fazenda Gold Farm, Vitoriana, Botucatu, São Paulo, Brazil, 01.X.1986, I.M.P. Rinaldi \& L.C. Forti leg., deposited in UBTU 2658.

Etymology. The species is named in honour of the Brazilian arachnologist Isabella M.P. Rinaldi, who collected one of the type specimens.

Diagnosis. Females of this species can be easily distinguished from others by the wide deep epigynal atrium (Figs 21 and 22).

Description. Female (holotype). Total length: 4.35. Carapace dark brown, 1.75 long, 1.10 wide, 0.65 high. Cephalic area black. Ocular quadrangle 0.85 long. Anterior eye row 0.90 wide and posterior 0.95 wide. Chelicera brown. Endite, labium and sternum dark brown. Legs 4132, yellow, I-II with longitudinal brown stripes. Length of femur: I 0.80 , II 0.65 , III 0.65 , IV 1.00; patella + tibia: I 1.00, II 0.75, III 0.70, IV 1.15; metatarsus + tarsus: I 0.55, II 0.55, III 0.75, IV 0.95. Spination. Femur I, II, III, IV d1-1-1; tibia I, II v1pr, III v2di, IV v2di, p1; metatarsus I, II v2-2, III, IV v1, p2di, r1di. Abdomen cream colored with a pair of wide longitudinal brown stripes laterally and a narrow longitudinal brown one; ventrally grayish. Epigynum as in figures 21 and 22. Spinnerets dark brown.

Male. Unknown.

Variation. Two females: total length: 4.35-4.45; carapace length: $1.75-1.80$.

Additional material examined. BRAzIL, Pará: Novo Progresso (Serra do Cachimbo, Campo de Provas Brigadeiro Velloso), 1 female, 8.IX-25.V.2003, A.B. Bonaldo leg. (IBSP 81049, exMPEG 1364).

Distribution. Known from the states of Pará and São Paulo, Brazil.

Revista Brasileira de Zoologia 25 (1): 139-147, March, 2008 
Note. This species has an epigynum much modified, but the remaining morphological characters are very similar to those of the group in which the type species is located. Its inclusion in the genus may be corroborated with the future description of the male.

\section{Helvetia roeweri (Soares \& Camargo, 1948) comb. nov.}

\section{Figs 23-24}

Naubolus roeweri Soares \& Camargo, 1948: 393, fig. 60 (female holotype from Chavantina, Mato Grosso, Brazil, XI.1946, Sick leg., deposited in MZSP 1290, examined); Platnick, 2007.

Diagnosis. Females of this species are easily distinguished from the remaining species of the genus by the fact that this is the only species in which the initial part of the copulatory ducts is directed toward the inner side of the epigynum (Fig. 23).

Description. Female (IBSP 78641). Total length: 4.05. Carapace reddish brown, 1.55 long, 0.90 wide, 0.55 high. Black rings around eyes and cephalic area with a pair of black spots. Ocular quadrangle 0.85 long. Anterior eye row 0.90 wide and posterior 0.95 wide. Chelicera brown. Endite, labium and sternum light brown. Legs 4312, yellow, with longitudinal stripes on the femora, tibiae and metatarsi. Length of femur: I 0.65, II 0.55, III 0.65, IV 0.90; patella + tibia: I 0.70, II 0.65, III 0.65, IV 1.05; metatarsus + tarsus: I 0.55 , II 0.50 , III 0.75 , IV 0.90. Spination. Femur I, II, III, IV d1-1-1; tibia I v1r-2-0, II v1r, III 0, IV v1rdi; metatarsus I, II v2-2, III, IV v1, p1, r2. Abdomen light brown, with two pairs of white spots anteriorly; ventrally grayish. Epigynum as in figures 23 and 24. Spinnerets light brown.

Male. Unknown.

Variation. Four females: total length: 3.70-4.15; carapace length: $1.55-2.10$.

Additional material examined. BraziL, Pará: Novo Progresso (Serra do Cachimbo, Campo de Provas Brigadeiro Velloso), 1 female, 8.IX-25.V.2003, D.R. Souza leg. (MPEG 1343); Mato Grosso do Sul: Costa Rica (Fazenda Pouso Frio, $18^{\circ} 39^{\prime} \mathrm{S}, 52^{\circ} 53^{\prime} \mathrm{W}$ ): 3 females, 29.III.2004, Equipe Jauru leg. (IBSP 78640-78641).

Distribution. Known from the states of Pará, Mato Grosso and Mato Grosso do Sul, Brazil.

Note. Since all the remaining species of this genus have the initial part of the copulatory ducts running to the lateral sides of the epigynum, it is possible that this species belongs to another lineage, maybe an undescribed genus.

\section{ACKNOWLEDGMENTS}

We wish to thank CNPq and FAPESP (06/55226-0) for financial support. We also thank G.B. Edwards for helpful suggestions on the manuscript and A.B. Bonaldo for donnation of material. This study is part of the BIOTA/FAPESP - The Biodiversity Virtual Institute Program (www.biotasp.org.br) and was developed in the Programa de Pós-Graduação do Instituto de Biociências, Universidade de São Paulo.

\section{LITERATURE CITED}

Banks, N. 1902. Papers from the Hopkins Stanford Galapagos Expedition; 1898-1899. VII. Entomological Results (6). Arachnida. With field notes by Robert E. Snodgrass. Proceedings of the Washington Academy of Science 4: 49-86.

GALIANO, M.E. 1963a. Las especies americanas de arañas de la familia Salticidae descriptas por Eugène Simon: Redescripciones basadas en los ejemplares típicos. Physis Buenos Aires (C) 23: 273470.

Galiano, M.E. 1963b. Nota sobre arañas del grupo Marpisseae (Araneae, Salticidae). Revista de la Sociedad Entomológica Argentina 24: 1-8.

Galiano, M.E. 1965. Descripción de Helvetia riojanensis sp. n. y del alotipo or de H. albovittata Simon (Araneae, Salticidae). Revista de la Sociedad Entomológica Argentina 27: 47-50.

Galiano, M.E. 1976. Dos nuevas especies del género Helvetia Peckham, 1894 (Araneae, Salticidae). Revista de la Sociedad Entomológica Argentina 35: 51-56.

Galiano, M.E. 1989. Note on the genera Admestina and Akela (Araneae, Salticidae). Bulletin of the British Arachnological Society 8: 49-50.

Maddison, W.P. \& M.C. Hedin. 2003. Jumping spider phylogeny (Araneae: Salticidae). Invertebrate Systematics 17: 529-549.

Mello-Leitão, C.F. de. 1943. Catálogo das aranhas do Rio Grande do Sul. Archivos do Museu Nacional do Rio de Janeiro 37: 147-245.

Mello-Leitão, C.F. DE. 1945. Arañas de Misiones, Corrientes y Entre Ríos. Revista del Museo de La Plata (Nova Serie, Zoología) 4: 213-302.

Peскнam, G.W. \& E.G. Pecкham. 1894. Spiders of the Marptusa group. Occasional Papers of the Natural History Society of Wisconsin 2: 85-156.

Platnick, N.I. 2007. The world spider catalog. Version 7.5. American Museum of Natural History, Electronic Database available at http://research.amnh.org/entomology/spiders/ catalog/index.html

Prószynski, J. 1976. Studium systematyczno-zoogeograflczne nad rodzina Salticidae (Aranei) Regionów Palearktycznego i Nearktycznego. Wyzsza Szkola Pedagogiczna Siedlcach 6: $1-260$.

SIMON, E. 1901a. Histoire naturelle des araignées. Paris, vol. 2, p. 381-668.

Simon, E. 1901b. Descriptions d'arachnides nouveaux de la famille des Attidae (suite). Annales de la Société Entomologique de Belgique 45: 141-161.

Soares, B.A.M. \& H.F. DE A. Camargo. 1948. Alguns novos salticidas do Brasil (Araneae, Salticidae). Revista Brasileira de Biologia 8: 421-443.

TACZANOWSKI, L. 1872. Les aranéides de la Guyane française. Horae Societatis Entomologicae Rossicae 9: 64-112.

Received in 19.VII.2007; accepted in 05.III.2008. 